Original Research

\title{
The Effect of Blended Learning on Nursing Students' Knowledge
}

\author{
Ni Gusti Ayu Eka , Grace Solely Houghty and Juniarta
}

Faculty of Nursing, Universitas Pelita Harapan, Tangerang, Indonesia

\begin{abstract}
Introduction: Blended learning is assumed to improve the students' understanding of learning at nursing school especially in the current industrial revolution 4.0 era. The combination of classroom and online activities is expected to provide better study outcomes. This research aimed to compare the knowledge scores of the nursing students in blended learning concerning a research and statistics course at a private faculty of nursing.
\end{abstract}

Methods: The knowledge scores resulted from the student's score in their mid and final examinations (0-100). A total of 474 respondents who were third year students involved in the study. This study applied a preexperimental design. Due to the data having a significant non-normal value ( $p$ value $<0.001$ ), this study further compared the mean-rank of the students' score using a Wilcoxon test analysis.

Results: The results of this study revealed that there was a significant difference ( $p$ value $<0.0001$ ) between the students' score in the mid (Median 72.5; SD 9.82) and final exam examinations (Median 86.66; SD 4.75). This means that the students had a better score in their final exam.

Conclusion: Applying a blended learning method was a positive experience for the nursing students in terms of knowledge. It is needed to explore the students' understanding and interest in their learning process using blended learning.

\section{ARTICLE HISTORY}

Received: Dec 26, 2019

Accepted: Dec 31, 2019

\section{KEYWORDS}

blended learning; nursing; student; knowledge

\section{CONTACT}

Ni Gusti Ayu Eka

$\triangle$ gusti.eka@uph.edu

$\fallingdotseq$ Faculty of Nursing, Universitas

Pelita Harapan, Tangerang, Indonesia

Cite this as: Eka, N. G, A., Houghty, G., \& Juniarta. (2019). The effect of blended learning on nursing students' knowledge. Jurnal Ners, 14(3si), 1-4. doi:http://dx.doi.org/10.20473/in.v14i3(si).16933

\section{INTRODUCTION}

Today's era of the fourth industrial revolution where human and technology are connected has had impact on all sectors, including the health system and higher education (WEF \& Schwab, 2017). Regarding higher education, the current era is also known as Higher Education 4.0 (HE 4.0). The HE 4.0 requires changing skills in the industry which demands a learning system alteration in the universities (Jhingan, 2017). Universities should provide comprehensive resources based on technology that supports the students' development related to problem solving and decision-making skills in order to follow along with the globalization of education(Muawiyah, Yamtinah, \& Indriyanti, 2018). The method of teaching also changes due to the current era, which it is important to consider regarding the instruments to aid the education process such as devices for supporting the teaching and learning process, such as
Massive Open Online Courses (MOOCs) applications and using of blended learning (Xing \& Marwala, 2017).

The term "blended learning" is argued as being a new term in relation to the era of HE 4.0 (Wright, 2017). Blended learning is a combination of face-toface traditional learning and online learning methods which suits the students by using various multimedia(Dziuban, Graham, Moskal, Norberg, \& Sicilia, 2018; Wright, 2017). A previous study reported that $35 \%$ of courses in higher education are using a blended learning design and that $12 \%$ of 12.2 million online teaching materials are included in the blended courses (Dziuban et al., 2018).

Blended learning could improve the clinical competencies of health students as reported by Rowe and their colleagues (Rowe et al., 2012) using a systematic review. McCutcheon and their colleagues (McCutcheon, Lohan, \& Traynor, 2016) further claimed in their systematic review study that there is 
a minimum evaluation of blended learning needed in nursing education. Both of these systematic reviews were limited to some areas of health education and there is no study in regard to blended learning effectiveness in health professions using a quantitative synthesis. To fill in these gaps, Liu and their colleagues (Shang \& Liu, 2018) conducted a systematic review to identify the effectiveness of blended learning for health professionals. Liu's study also compared blended learning with non-blended learning. Liu's study concluded that blended learning could have a positive effect in comparison with no intervention. Blended learning was also more effective than non-blended learning for knowledge achievement in health professions. However, due to the enormous heterogeneity of the chosen studies in Liu's study, the above conclusion should be interpreted with caution.

To become involved in the era of HE 4.0, the Faculty of Nursing (FoN) in Universitas Pelita Harapan (UPH) Tangerang, supported by the Directorate of Higher Education in Indonesia that known as DIKTI, developed a blended course called Research and Statistics (RS). This course is one of the mandatory nursing courses for students in their third year at FoN UPH. The RS course is designed to encourage the students to understand the interrelationship between theory, research, and practice based on scientific evidence in the development of nursing knowledge and in the improvements in the quality of the nursing services. Students are given the opportunity to develop an understanding of the stages of the research process, to gain knowledge, to apply critical thinking skills in research within the scope of nursing, and to apply skills in the development of research in an ethical way. In order for the course to be sustainable learning, a number of appropriate assessments are required in the blended learning design. The RS course provides four main assessments including a weekly quiz, mid-term exam, critique paper and final exam. However, in this study, we only compared the students' scores between the mid and final exams. The reason for this is that both scores assessed the students' knowledge in an equal time span (half semester). To pass the course, the students should get 70 or a B-for their final score. This study aims to compare the knowledge scores of the nursing students in the blended learning of their research and statistics course at FoN UPH.

\section{MATERIALS AND METHODS}

Blended learning was applied using a learning management system (LMS), Moodle, provided by the Universitas Pelita Harapan website (http://learn.uph.edu/). The LMS provides online course management, in this case, a research and statistics course which contains learning sources such as the course outline, videos, articles and assessments.
The participants were the third-year students at the Faculty of Nursing in Universitas Pelita Harapan. There were 474 students registered on the research and statistics course. Thus, the respondents of this study were all of the students who were involved in the teaching-learning of the RS course. The students were informed of the study and agreed verbally. The students were divided into 10 groups and then, were divided into three big groups for classroom activities. The following are the learning activities in the blended learning.

To achieve the objective of the current study, a pre-experimental research design was applied(Polit \& Beck, 2012). A two times-test was employed to measure the students' knowledge in the mid and final examinations. The mid examinations consisted of 40 multiple choice questions which were developed by the teaching team. The questions had been developed and revised over the past three years by evaluating each item using its facility index in the LMS. The final examination score was the result of team work by developing a proposal in a group of 10 students. The rubric for the proposal evaluation was developed by team teaching, which had been evaluated over the past three years. In this study, the knowledge scores resulted from the students' score in their mid and final examinations (0-100).

Since the data distribution of the students' knowledge scores was abnormal, a Wilcoxon test was conducted to compare the mean rank of the students' scores(Field, 2013). The Wilcoxon test aimed to identify whether the mean rank of the two-times test was significantly different after experiencing blended learning (Polit \& Beck, 2012).

Regarding the ethical considerations, the Mochtar Riady Institute for Nanotechnology Ethics Committee provided approval for this study (No. 016/MRINEC/ECL/X/2018). In addition, the private faculty of nursing in which the study took place also gave permission for this study to be conducted.

\section{RESULTS}

The 474 students completed their mid-term and final exams. The results of the students' knowledge score can be seen in Table 1. The result of this study revealed that there was a significant difference $(\mathrm{Z}=$ 18.43; p value $<0.0001$ ) between the students' score in the mid-term examination (Median 72.5; Standard Deviation 9.82) and their score in the final examination (Median 86.66; Standard Deviation 4.75). This also means that the students had a better score in their final-term exam. This study also calculated the approximate effect size manually $(\mathrm{r}=$ $\mathrm{Z} / \sqrt{\mathrm{N}}$ ) (Field, 2013). The effect size of this study was above moderate $(r=-0.85)$. The result shows that blended learning had a large influence on the students' knowledge. However, the final exam score was the result of team work by developing a proposal in a group of 10 students. Meanwhile, the mid-term exam was from an individual multiple choice test. This condition could be a possible difference of 
Table 1. Learning activities in blended learning

\begin{tabular}{ll}
\hline Steps & \multicolumn{1}{c}{ Blended Learning } \\
\hline Prior to lesson & $\begin{array}{l}\text { Students view specific presentations relevant to the upcoming tutorial via the } \\
\text { university's learning management system (LMS) } \\
\text { Lecturer facilitates discussion with the students on the key concepts that are to be } \\
\text { covered in the module } \\
\text { Students are divided into small groups }\end{array}$ \\
& $\begin{array}{l}\text { Lecturers facilitates discussion based on the content raised in the specific activity } \\
\text { Post lesson }\end{array}$ \\
Prior to lesson & $\begin{array}{l}\text { Students view specific presentations relevant to the upcoming tutorial via the } \\
\text { university's LMS } \\
\text { Designated lesson }\end{array}$ \\
\hline
\end{tabular}

Table 2. Data description of Students Knowledge Score $(n=474)$

\begin{tabular}{cccc}
\hline Data Measurement & Mid Exam Score & Final Exam Score & Wilcoxon test results \\
\hline Mean & 71.38 & 86.75 & \\
Median & 72.50 & 86.38 & $\mathrm{Z}=-18.43$ \\
Mode & 72.50 & 86.38 & $\mathrm{p}$ value $<0.0001$ \\
Std. Deviation & 9.82 & 2.58 & $\mathrm{r}=-0.85$ \\
Variance & 96.55 & 6.70 & \\
Minimum & 45.00 & 81.75 & \\
Maximum & 95.00 & 92.50 & \\
\hline
\end{tabular}

individual contributions (Gagnon, Gagnon, Desmartis, \& Njoya, 2013) that might further influence the students' achievements.

\section{DISCUSSION}

This study showed that blended learning had an influence on the nursing students' achievements over the course of the research and in the statistics ( $\mathrm{p}$ value $<0.0001$ ).The findings of a previous systematic review study with a meta-analysis (Kang \& Seomun, 2018) are consistent with the current study that blended learning increased the participants' knowledge in nursing education. This achievement could not be separated from the learning process of the students. The process of the student's learning included watching videos, weekly quizzes and article reading before the class meeting. A previous systematic review of blended learning in clinical practice informed us that blended learning has been implemented in many different approaches using many different tools(Rowe et al., 2012). The study further mentioned that the chosen tools in blended learning should be the best to achieve the learning outcomes(Rowe et al., 2012).

A comparison study between blended learning and traditional learning within one nursing program in China also supported that $68 \%$ of the student participants favored the blended course over the traditional face-to-face course(Shang \& Liu, 2018). In addition, the final examination results revealed that the students' scores in the blended course were significantly better than students in the traditional classroom ( $p$ value < 0.01) (Shang \& Liu, 2018). However, blended learning was not always evident in better scores but it can improve the clinical skills of the students(Rowe et al., 2012). This also means that using the blended learning approach could bridge the knowledge gap between theory and practice in nursing education.
Moreover, contrary to the findings of the current study, a randomized control trial study focused on one nursing program in Canada (Gagnon et al., 2013) revealed that the blended teaching method did not affect the students' knowledge directly. It was further mentioned that the learners motivation should be involved in the learning. Motivation and learning are interconnected(Schiefele, 1991), in which motivation affects the individual's ability to learn as well as the intensity and length of the individuals' learning (Bandura, 1991). Interestingly, a comparative study of the students' motivation between traditional faceto-face learning and online learning revealed that the students who did online learning had stronger intrinsic motivation than the students in traditional face-to-face classes(Rovai, Ponton, Wighting, \& Baker, 2007). However, there were no significant differences for the students' extrinsic motivation and amotivation(Rovai et al., 2007). Moreover, Gagnon and their colleagues conducted a study of motivation (one-time measurement) and suggested that less motivated students could get an advantage from elearning(Gagnon et al., 2013).

\section{CONCLUSION}

This study indicates that blended learning has influenced the students' knowledge. The most important thing to be aware of is the process of the students learning using mixed teaching methods. This means that blended learning could accommodate the student's learning by providing multiple sources. Blended learning is also a positive experience for the nursing students in term of knowledge. Further study is needed to explore the students' understanding and interest in the teaching-learning process using blended learning.

\section{REFERENCES}

Bandura, A. (1991). Human Agency The Rhetoric. 
Dziuban, C., Graham, C. R., Moskal, P. D., Norberg, A., \& Sicilia, N. (2018). Blended learning: the new normal and emerging technologies. International Journal of Educational Technology in Higher Education, 15(1), 1-16. https://doi.org/10.1186/s41239-017-0087-5

Field, A. (2013). Discovering Statistics using IBM SPSS Statistics (4th ed.). SAGE Publications Ltd.

Gagnon, M., Gagnon, J., Desmartis, M., \& Njoya, M. (2013). The Impact of Blended Teaching on Knowledge, Satisfaction, and Self-Directed Learning in Nursing Undergraduates: A Randomized, Controlled Trial, 34(6), 377-383. https://doi.org/10.5480/10-459

Jhingan, A. (2017). Leapfrogging to Student at the core, (November).

Kang, J., \& Seomun, G. A. (2018). Evaluating WebBased Nursing Education's Effects: A Systematic Review and Meta-Analysis. Western Journal of Nursing Research, 40(11), 1677-1697. https://doi.org/10.1177/0193945917729160

McCutcheon, K., Lohan, M., \& Traynor, M. (2016). A systematic review protocol on the use of online learning versus blended learning for teaching clinical skills to undergraduate health professional students. Higher Education Pedagogies, 1(1), 82-88. https://doi.org/10.1080/23752696.2015.11342 04

Muawiyah, D., Yamtinah, S., \& Indriyanti, N. Y. (2018). Higher education 4.0: Assessment on environmental chemistry course in blended learning design. Journal of Physics: Conference Series, $1097(1)$, $0-7$. https://doi.org/10.1088/17426596/1097/1/012058
Polit, D. F., \& Beck, C. T. (2012). Nursing Research, Generating and Assessing Evidence for Nursing Practice. Baltimore: Wolters Kluwer Health.

Rovai, A. P., Ponton, M. K., Wighting, M. J., \& Baker, J. D. (2007). A Comparative Analysis of Student Motivation in Traditional Classroom and ELearning Courses - ProQuest. International Journal on ELearning, 6(3), 413-432.

Rowe, M., Frantz, J., Bozalek, V., Rowe, M., Frantz, J., \& Bozalek, V. (2012). The role of blended learning in the clinical education of healthcare students: A systematic review the role of blended learning in the clinical education of healthcare students: A systematic review. https://doi.org/10.3109/0142159X.2012.64283 1

Schiefele, U. (1991). Perspektiven Interest, Learning, and Motivation. Educational Psychologist, (April 2013), 37-41.

Shang, F., \& Liu, C.-Y. (2018). Blended learning in medical physiology improves nursing students' study efficiency. Advances in Physiology Education, 42(4), 711-717. https://doi.org/10.1152/advan.00021.2018

WEF, \& Schwab, K. (2017). The Fourth Industrial Revolution, by Klaus Schwab | World Economic Forum. World Economic Forum, 1-5. https://doi.org/978-1-5247-5886-8

Wright, B. M. (2017). Blended Learning: Student Perception of Face-To-Face and Online Efl Lessons. Indonesian Journal of Applied Linguistics, $7(1), \quad 64$. https://doi.org/10.17509/ijal.v7i1.6859

Xing, B., \& Marwala, T. (2017). Implications of the Fourth Industrial Age on Higher Education, 1015. 